\title{
Yoğun Bakım Ünitesinde Tedavi Gören Hastaların Deneyimlerinin Belirlenmesi
}

\author{
(1) Işılay Dinlegör Sekmen, ${ }^{1}$ (1) Serap Ünsar² \\ ${ }^{1}$ Edirne Sultan 1. Murat Devlet Hastanesi, Edirne, Turkey \\ ${ }^{2}$ Trakya Üniversitesi Sağlık Bilimleri Fakültesi Hemşirelik Bölümü İç Hastalıkları Hemşireliği Anabilim Dalı, Edirne, Turkey
}

\begin{abstract}
Özet
Amaç: Çalışma yoğun bakım ünitesinde tedavi gören hastaların yoğun bakım deneyimlerini ve etkileyen faktörleri belirlemek amacıyla planlandı.

Yöntemler: Araştırma Edirne ilindeki bir üniversite hastanesi Koroner Yoğun Bakım Ünitesinde yatarak tedavi gören ve rastlantısal örneklem yolu ile seçilen toplam 107 hasta ile yürütüldü. Çalışmanın verileri Yoğun Bakım Deneyim Ölçeği (YBDÖ) kullanılarak elde edildi. Verilerin analizinde SPSS 19.0 programında, yüzdelik, ortalama, Mann Whitney-U testi, Kruskal-Walis $\mathrm{H}$ testi tekniği kullanıldı.

Bulgular: Yoğun bakım hastalarının yaş ortalaması 62.07士11.4 idi. Hastaların yoğun bakım deneyim ölçeği genel toplam puan ortalamaları 67.0 \pm 8.56 (min-max: 38.0-80.0) idi. Erkek hastaların kadın hastalara oranla, genel olarak 61 yaş ve üstünde olan hastaların 60 yaş ve altında olan hastalara oranla ve bekar hastaların evli hastalara oranla, yoğun bakım deneyimlerinin daha pozitif olduğu belirlendi ( $p<0.05$ ).Yoğun bakımda 1-5 gün arasında yatan ve girişimsel kardiyoloji işlemi için yatışı yapılmış yoğun bakım hastalarının yoğun bakım deneyimlerinin diğer gruplara göre daha pozitif olduğu belirlendi $(p<0.05)$.

Sonuç: Bu sonuçlar doğrultusunda hastaların yoğun bakıma yatış sırasındaki negatif deneyimlerinin azaltılmasına yönelik bireysel (yaş, cinsiyet vb.) ve hastalığa ilişkin (klinik tanı, yoğun bakımda kalma süresi) özellikler göz önünde bulundurularak hemşirelik bakımının planlanması ve uygulanmasının yoğun bakım hastalarının iyileşme düzeylerine katkı sağlayacağı düşünülmektedir.
\end{abstract}

Anahtar sözcükler: Akut koroner sendrom; hemşirelik; yoğun bakım ünitesi; yoğun bakım deneyimi; yoğun bakım deneyim ölçeği.

\section{Determining the Experiences of the Patients who were being Treated in Intensive Care Unit}

\footnotetext{
Abstract

Objective: The current study was planned to examine the factors affecting intensive care experience of patients who were being treated in intensive care unit.

Methods: The study was run with total 107 patients who was choosen in the way of random sampling and got inpatient treatment in the city of Edirne's university hospital Cardiology Intensive Care Unit. Data of the study were obtained by intensive care experience scale. On the analyses of data were used in the program SPSS 19.0, percentage, average, Mann Whitney $\mathrm{U}$ test, the technique of Kruskall-Wallis $\mathrm{H}$ test.

Results: It was found that the average age of the intensive care patients $62.07 \pm 11.4$. It was determined that intensive care experience scale total point average of patients were 67.0 \pm 8.56 (min-max: 38.0-80.0). It was determined that intensive care experi-
}

\footnotetext{
İletişim (Correspondence): Dr. Serap Ünsar. Trakya Üniversitesi Sağlık Bilimleri Fakültesi Hemşirelik Bölümü, Iç Hastalıkları Hemşireliği Anabilim Dalı, Edirne, Turkey

Telefon (Phone): +90 2842133042 E-Posta (E-mail): serapunsar@trakya.edu.tr

Başvuru Tarihi (Submitted Date): 29.03.2018 Kabul Tarihi (Accepted Date): 03.01.2019

OCopyright 2018 by Turkish Society of Cardiology - Available online at www.anatoljcardiol.com
} 
ences of male patients more positive to females, intensive care experiences of patients who 61 years and older more positive to 60 years and lower age, intensive care experiences of single patients more positive to married patients $(p<0.05)$. It was found that intensive care experience scale point average of the patients who stayed in intensive care between 1-5 days were more positive to the ones who stayed 6 days and more. It was determined that patients in the diagnosis of interventional cardiology group intensive care experiences point averages more positive to another disease diagnosis group $(\mathrm{p}<0.05)$.

Conclusion: In the direction of this results negative experiences of during the admission to intensive care to decrease, considering the features which related to disease (diagnose, duration of stayed in intensivecareetc.) and personal (age, genderetc.), it was thought that planning and performing nursing care will contribute the level of recovery of intensive care patients.

Keywords: Acute coronary syndrome; intensive care unit; intensive care experience; intensive care experience scale; nursing.

Cite this article as: Dinlegör Sekmen I, Ünsar S. Determining the Experiences of the Patients who were being Treated in Intensive Care Unit. Turk J Cardiovasc Nurs 2018;9(20):113-119.

Y oğun bakım üniteleri (YBÜ), klinik olarak durumu kritik düzeyde olan hastaların takip edilerek, tedavi ve bakımda ekip yaklaşımı gerektiren, teknolojik açıdan biyomedikal cihazların yer aldığı, özellikli üniteler olarak tanımlanmaktadır. ${ }^{[1]}$ Yoğun bakım ünitelerinde amaç, hayat kurtarmakla birlikte hasta ve ailesini psikososyal ve fiziksel yönden destelemek ve hastaların yoğun bakıma yönelik pozitif deneyimlerle taburcu olmasına katkı sağlamaktır. [2] Hayati tehlikesi bulunan şuuru açık hastaların monitörize edilmesi, idrar sondası infüzyon setleri takılması gibi etmenlerle yatağa bağımlı olmakta, birçok biyomedikal araç ve gereçlerin çıkardığı sesler ve sık yinelenen ağrıı girişimlere maruz kalabilmektedirler. Aynı zamanda hastalar; yoğun bakımda tedavi gerektiren durumlar, izolasyon, gece-gündüz kavramının kaybolması ve uyku düzeninin bozulması, bilinmeyen çevre ve bireyler, aile bireylerini görememe, tedavi, hastalık süreci ve uygulanan girişimler konusunda sağlık personeli tarafından yeterli düzeyde bilgi verilmemesi gibi sebeplerden psikososyal olarak olumsuz yönde etkilenebilmektedirler. ${ }^{[3-5]}$ YBÜ'nde hastaların psikososyal olarak yaşadığı sorunlar kişinin sağlığını olumsuz etkilemekte, hastanın tedavi ve bakım sürecini ve hastanede yatış süresini uzatmaktadır. ${ }^{[6]}$ Hastalık sürecinde hastanın yaşadıklarına verdiği anlam sonucu oluşan fiziksel ve emosyonel tepkiler yoğun bakım hemşiresi tarafından fark edilerek bütüncül bakımı sağlanmalıdır. ${ }^{[7]}$

Ülkemizde kalp ve damar hastalıkları ölüm nedenleri arasında \%47.73 ile ilk sırada yer almaktadır. ${ }^{[8]}$ Tüm bu veriler ışığında yoğun bakıma yatışların en sık nedeni olarak karşımıza kalp ve damar hastalıkları çıkmaktadır. ${ }^{[8-11]}$ Ülkemizde yoğun bakım ortamında tedavi gören bireylerin fiziksel açıdan bakım gereksinimleri karşılanmaktadır. Ancak hastaların YBÜ'de hangi deneyimleri olumlu/olumsuz olarak yaşadığı ve duygusal durumlarının farkına tam olarak varılmamaktadır. ${ }^{[13]}$ Literatürde, hastaların yoğun bakım deneyimlerini etkileyen en önemli faktörün, hemşirelik bakım girişimleri olduğu saptanmıştır. Bu nedenle; nitelikli hemşirelik bakımı, hemşirenin sürekli hastayı izlemesi, fiziksel yönden olduğu kadar spiritüel yönden de ele alınması ve hasta ile etkili iletişim kurması vb. ile hastalar daha olumlu yoğun bakım deneyimlerine sahip olmaktadır. Yoğun bakım ünitelerinde görev yapan sağlık personelinin bakım ve teknolojik konularda becerilere sahip olması ve etkili iletişim teknikleri kullanma$\mathrm{sl}$, hasta bireylerin kendilerini daha güvende hissetmelerine yol açmaktadır. ${ }^{[2]}$ Hastaların kritik dönemlerinde sürdürülen bakımın ve rehabilitasyonun en önemli aşaması olan yoğun bakım sürecinde anksiyete, korku, depresyon ve olumsuz sağlık davranışlarına neden olabilecek faktörlerin ve etkileme düzeylerinin değerlendirilmesi, bakım gereksinimlerinin belirlenmesinde önemlidir. ${ }^{[14]}$ Yoğun bakım ünitesinde tedavi gören hastalar hemşireleri sürekli gözlem yapan, öz bakımlarını destekleyen ve geliştiren, bakım veren ve kaygılarını azaltan bireyler, hekimleri de güvenli bilgi kaynağı olarak görmektedirler. ${ }^{[14]}$ Bu bilgiler çerçevesinde, yoğun bakım hemşirelerine bakım verici rolünün dışında, oldukça önemli görevler ve sorumluluklar düşmektedir. Yoğun bakım hemşirelerinin, hastaların yoğun bakımda yaşadıkları deneyimleri tespit etmeleri ve bu deneyimleri olumlu yönde geliştirilebilecek nitelikli hemşirelik bakımını planlamalıdırlar. Araştırmadan elde edilen bulguların hemşirelere yoğun bakımda tedavi gören hasta bireylerin, yoğun bakım deneyimlerinin daha olumlu yönde olabilmesi için uygun hemşirelik girişimlerini planlayabilmede yol gösterici olacağı düşünülmektedir. Bu doğrultuda araştırma yoğun bakım ünitesinde tedavi gören hastaların deneyimleri ve etkileyen faktörleri belirlemek amacıyla planlandı.

\section{Gereç ve Yöntem}

\section{Araştırmanın Şekli}

Bu araştırma yoğun bakım ünitesinde tedavi gören hastaların yoğun bakım deneyimlerini etkileyen faktörleri incelemek amacıyla planlanan tanımlayıcı tipte kesitsel bir araştırmadır. Araştırmanın örneklemini 01/06/2014 ve 01/01/2015 tarihleri arasında, Edirne ilinde bir Tıp Fakültesi Hastanesi Koroner Yoğun Bakım Ünitesinde yatarak tedavi gören, araştırmaya kabul kriterlerini karşılayarak 
araştırmaya katılmayı kabul eden, rastlantısal örneklem yolu ile seçilmiş 18 yaş ve üstü yoğun bakım yatışının üzerinden en az 24 saat geçmiş toplam 107 yoğun bakım hastası oluşturdu.

\section{Veri toplama araçları}

Araştırmanın verileri hastaların kişisel özelliklerine ilişkin tanıtıcı form ve Yoğun Bakım Deneyim Ölçeği (YBDÖ) kullanılarak toplandı.

\section{Hasta Bilgi Formu}

Hasta tanıtım formu, araştırmacılar tarafından literatür taranarak hazırlanan, kişisel özellikleri, kaldığı oda tipi, yoğun bakıma yatış sayısı, yoğun bakımda kalma süresi, ex görme durumu, fiziksel kısıtlama durumu, mekanik ventilasyona bağlanma durumu, mekanik ventilasyona bağlı kalma süresi, yakınları ile görüşme durumu, kesin yatak istirahat süresi ile ilgili soruları içermektedir. ${ }^{[13,14,17,20-23]}$

\section{Yoğun Bakım Deneyim Ölçeği}

Yoğun Bakım Deneyim Ölçeği, 2004 yılında yoğun bakım hastalarının yaşadıkları deneyimleri değerlendirmek amacıyla Rattray ve ark.tarafından geliştirilmiştir. ${ }^{[15]}$ Ölçek Türkçe'ye Demir, Akın, Eşer ve Khorshid tarafından uyarlanmıs, Cronbach's alpha değeri 0.79 olarak belirlenmiştir.[19] Bu araştırmada Cronbah's Alpha değeri 0.67 olarak belirlendi. Ölçek 19 maddeden oluşmakta ve beşli likert tipindedir. Bu maddelerden 9'u hastanın yoğun bakıma olan uyumunu ve diğer 10 madde ise hastanın yaşadığı emosyonel duyguların sıklığını değerlendirmektedir. Ters puanlanan; 7, 8, 9, 10,15 ve 17. sorulardır. Bakım Deneyim Ölçeği'nin toplam puanı 19-95 arasındadır. Hastanın yoğun bakıma olan uyumunu değerlendirmek üzere hazırlanmış olan maddeler; "1-Kesinlikle katılıyorum (1 puan), 2-Katılıyorum (2 puan), 3-Kararsızım (3 puan), 4-Katılmıyorum (4 puan), 5-Kesinlikle katılmıyorum (5 puan)" şeklinde, hastanın yaşadığı emosyonel duyguların sıklığını belirleyen maddeler "1- Her zaman (1 puan), 2-Çoğu zaman (2 puan), 3-Bazen (3 puan), 4-Nadiren (4 puan), 5-Hiçbir zaman (5 puan)" şeklinde değerlendirilmektedir. Yoğun Yoğun Bakım Deneyim Ölçeği F1 "yoğun bakımda iken çevrenin farkında olma (1-6) (6-30 puan)", F2 "yaşanan kötümser deneyimler (7-10) (4-20 puan)", F3 "yoğun bakımda yaşanan deneyimlerin hatırlanması (15-19) (5-25 puan)" ve F4 "yoğun bakım ünitesindeki bakımdan memnuniyet (11-14) (4-20 puan)" alt boyutlarından oluşmaktadır. Ölçekten düşük puanlar alınması, bilinç durumunun yeterince açık olmadığı ve hastaların yoğun bakımda yaşadıkları deneyimlerin olumsuz olduğu; ölçekten yüksek puanlar alınması ise farkındalığın yüksek olduğu, yoğun bakımda yaşanılan deneyimlerin daha olumlu olduğu şeklinde değerlendirilmektedir. ${ }^{[18,24]}$

\section{Araştırmanın Etik Yönü}

Çalışma için Trakya Üniversitesi Tıp Fakültesi Etik Kurul'dan, Trakya Üniversitesi Sağıık Araştırma ve Uygulama Merkezi Başhekimliğinden, Trakya Üniversitesi Sağlık Araştırma ve Uygulama Merkezi Kardiyoloji Anabilim Dalı'ndan gerekli izinler alındı. Araştırmada insan olgusunun kullanımı kişisel hakların korunmasını gerektirdiği için çalışma boyunca "Insan Hakları Helsinki Deklerasyonu" na sadık kalındı (Etik Kurul no: 09/12).

\section{Bulgular}

Araştırmaya katılan yoğun bakım hastalarının \%53.3'ünün 61 yaş ve üstünde, \%70.1'inin erkek, \%85.0'inin evli, \%63.6'sı ilköğretim mezunu, \%46.7'sini akut koroner sendrom tanısı ile tedavi gördüğü, \%87.9'unun yoğun bakımda kalma süresinin 1-5 gün arasında olduğu bulundu (Tablo 1).

Araştırmaya katılan 61 yaş ve üstünde olan yoğun bakım hastalarının yoğum bakım deneyim ölçeği toplam puan, çevrenin farkında olma alt grup puan ortalaması 60 yaş ve altı grubuna göre daha yüksek ve olumlu bulundu. 49 yaş ve altındaki hastaların yaşanan kötümser deneyimleri alt grup puan ortalaması 50 yaş ve üstü gruba göre daha yüksek ve olumlu bulundu $(p<0.05)$ (Tablo 2$)$.

Erkek yoğun bakım hastalarının yoğun bakım deneyim

\begin{tabular}{|c|c|c|}
\hline Tanıtıcı özellikler & Sayı (N) & Yüzde (\%) \\
\hline \multicolumn{3}{|l|}{ Yaş } \\
\hline $49 \leq$ & 18 & 16.8 \\
\hline $50-60$ & 32 & 29.9 \\
\hline $61 \geq$ & 57 & 53.3 \\
\hline \multicolumn{3}{|l|}{ Cinsiyet } \\
\hline Kadın & 32 & 29.9 \\
\hline Erkek & 75 & 70.1 \\
\hline \multicolumn{3}{|l|}{ Medeni durum } \\
\hline Evli & 91 & 85.0 \\
\hline Boşanmış & 16 & 15.0 \\
\hline \multicolumn{3}{|l|}{ Eğitim durumu } \\
\hline Okur-Yazar & 11 & 10.3 \\
\hline İlköğretim & 68 & 63.6 \\
\hline Orta öğretim & 18 & 16.8 \\
\hline Üniversite ve üstü & 10 & 9.3 \\
\hline \multicolumn{3}{|l|}{ Klinik tanı } \\
\hline Akut koroner sendromlar & 50 & 46.7 \\
\hline Girişimsel kardiyolojik işlem & 43 & 40.2 \\
\hline Diğer & 14 & 13.1 \\
\hline \multicolumn{3}{|l|}{ Yoğun bakımda kalma süresi } \\
\hline $1-5$ & 94 & 87.9 \\
\hline $6 \geq$ & 13 & 12.1 \\
\hline
\end{tabular}


ölçeği genel puan ortalaması,yaşanan deneyimlerin hatırlanması,bakımdan memnuniyet alt boyut puan ortalaması kadın yoğun bakım hastalarından daha yüksek ve olumlu bulundu $(p<0.05)$ (Tablo 3).
Yoğun bakımda tedavi gören bekar hastaların yoğun bakım deneyim ölçeği genel puan ortalaması ve bakımdan memnuniyet alt grup puan ortalamaları ve yoğun bakım deneyimleri alt grup puan ortalamaları, evli hastaların puan orta-

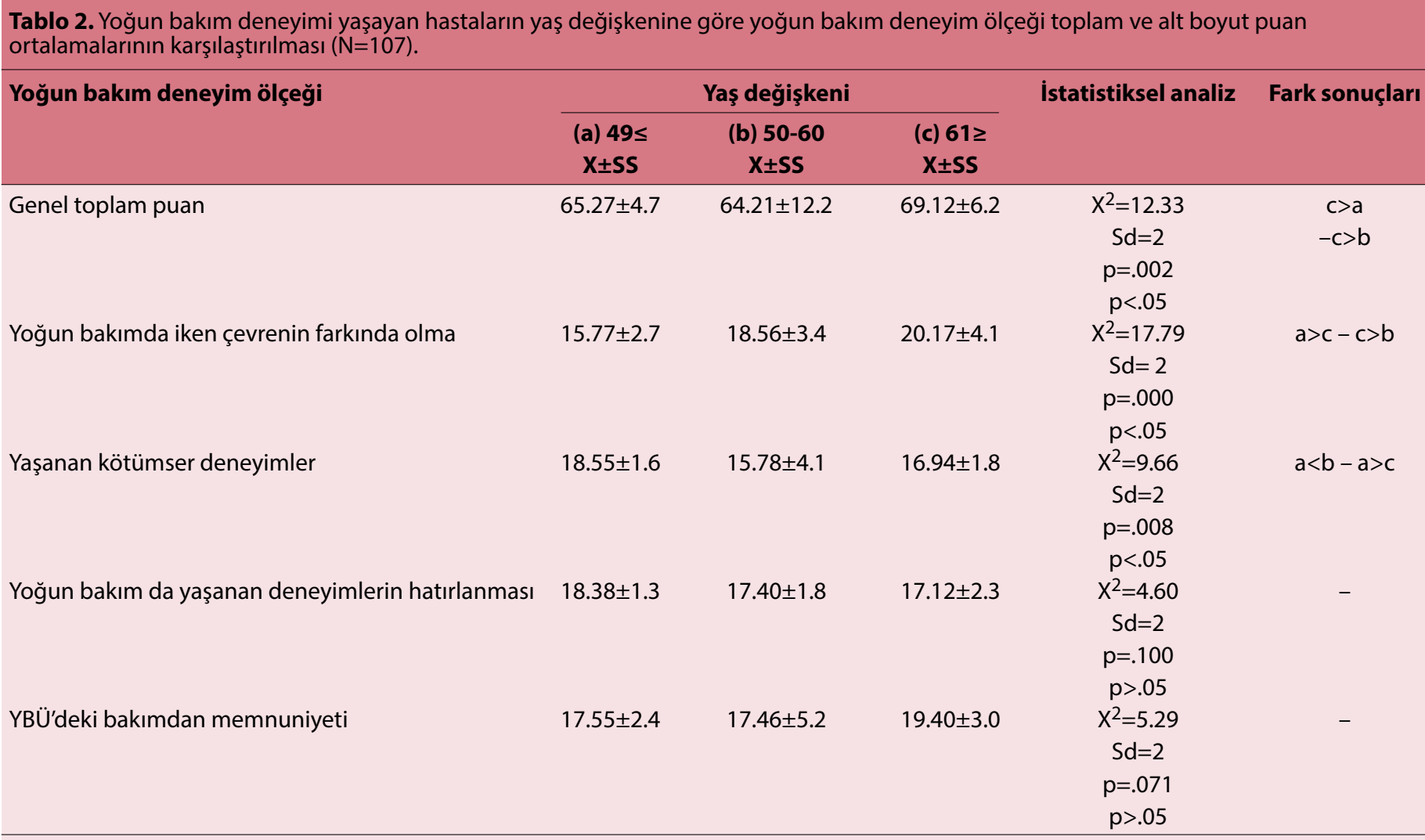

Tablo 3. Yoğun bakım deneyimi yaşayan hastaların cinsiyete göre yoğun bakım deneyim ölçeği toplam ve alt boyut puan ortalamalarının karşılaştırılması ( $\mathrm{N}=107)$.

\begin{tabular}{|c|c|c|c|}
\hline \multirow[t]{3}{*}{$\begin{array}{l}\text { Yoğun bakım } \\
\text { deneyim ölçeği }\end{array}$} & \multicolumn{2}{|c|}{$\begin{array}{l}\text { Cinsiyet } \\
\text { değişkeni }\end{array}$} & \multirow[t]{3}{*}{$\begin{array}{l}\text { İstatistiksel } \\
\text { analiz }\end{array}$} \\
\hline & Kadın & Erkek & \\
\hline & $\mathrm{X} \pm \mathrm{SS}$ & $\mathrm{X} \pm \mathrm{SS}$ & \\
\hline Genel toplam puan & $62.62 \pm 11.16$ & $68.88 \pm 6.40$ & $\begin{array}{c}\mathrm{U}: 883.5 \\
\mathrm{p}: .031 \\
\mathrm{p}<.05\end{array}$ \\
\hline $\begin{array}{l}\text { Yoğun bakımda iken } \\
\text { çevrenin farkında olma }\end{array}$ & $18.96 \pm 4.65$ & $18.94 \pm 3.78$ & $\begin{array}{c}\text { U: } 1162.5 \\
\text { p: } .798 \\
p>.05\end{array}$ \\
\hline $\begin{array}{l}\text { Yaşanan kötümser } \\
\text { deneyimler }\end{array}$ & $16.00 \pm 3.50$ & $17.24 \pm 2.43$ & $\begin{array}{c}\mathrm{U}: 956.0 \\
\mathrm{p}: .094 \\
\mathrm{p}>.05\end{array}$ \\
\hline $\begin{array}{l}\text { Yoğun bakımda yaşanan } \\
\text { deneyimlerin hatırlanması }\end{array}$ & $15.75 \pm 2.09$ & $18.13 \pm 1.70$ & $\begin{array}{c}\text { U: } 409.5 \\
\text { p: } .000 \\
p<.05\end{array}$ \\
\hline $\begin{array}{l}\text { YBÜ'deki bakımdan } \\
\text { memnuniyeti }\end{array}$ & $16.21 \pm 4.66$ & $19.49 \pm 2.93$ & $\begin{array}{c}\mathrm{U}: 659.0 \\
\mathrm{p}: .000 \\
\mathrm{p}<.05\end{array}$ \\
\hline
\end{tabular}

Tablo 4. Yoğun bakım deneyimi yaşayan hastaların medeni durum değişkenlere göre yoğun bakım deneyim ölçeği toplam ve alt boyut puan ortalamalarının karşılaştırılması ( $N=107)$.

\begin{tabular}{|c|c|c|c|}
\hline \multirow[t]{2}{*}{$\begin{array}{l}\text { Yoğun bakım } \\
\text { deneyim ölçeği }\end{array}$} & \multicolumn{2}{|c|}{$\begin{array}{c}\text { Medeni durum } \\
\text { değişkeni }\end{array}$} & \multirow[t]{2}{*}{$\begin{array}{l}\text { İstatistikse } \\
\text { analiz }\end{array}$} \\
\hline & $\begin{array}{c}\text { Evli } \\
\text { X } \pm S S\end{array}$ & $\begin{array}{l}\text { Bekar } \\
\text { X } \pm S S\end{array}$ & \\
\hline Genel toplam puan & $66.50 \pm 8.78$ & $71.0 \pm 3.76$ & $\begin{array}{l}\mathrm{U}: 360.0 \\
\mathrm{p}: .037 \\
p<.05\end{array}$ \\
\hline $\begin{array}{l}\text { Yoğun bakımda iken } \\
\text { çevrenin farkında olma }\end{array}$ & $18.75 \pm 4.16$ & $20.50 \pm 2.61$ & $\begin{array}{l}U: 423.0 \\
p: .145 \\
p>.05\end{array}$ \\
\hline $\begin{array}{l}\text { Yaşanan kötümser } \\
\text { deneyimler }\end{array}$ & $16.70 \pm 2.94$ & $18.16 \pm 1.11$ & $\begin{array}{l}\mathrm{U}: 414.0 \\
\mathrm{p}: .120 \\
\mathrm{p}>.05\end{array}$ \\
\hline $\begin{array}{l}\text { Yoğun bakımda } \\
\text { yaşanan deneyimlerin } \\
\text { hatırlanması }\end{array}$ & $17.66 \pm 2.06$ & $15.50 \pm 1.56$ & $\begin{array}{l}\mathrm{U}: 216.0 \\
\mathrm{p}: .000 \\
\mathrm{p}<.05\end{array}$ \\
\hline $\begin{array}{l}\text { YBÜ'deki bakımdan } \\
\text { memnuniyeti }\end{array}$ & $18.22 \pm 3.90$ & $20.83 \pm 2.03$ & $\begin{array}{l}\mathrm{U}: 317.0 \\
\mathrm{p}: .012 \\
p<.05\end{array}$ \\
\hline
\end{tabular}




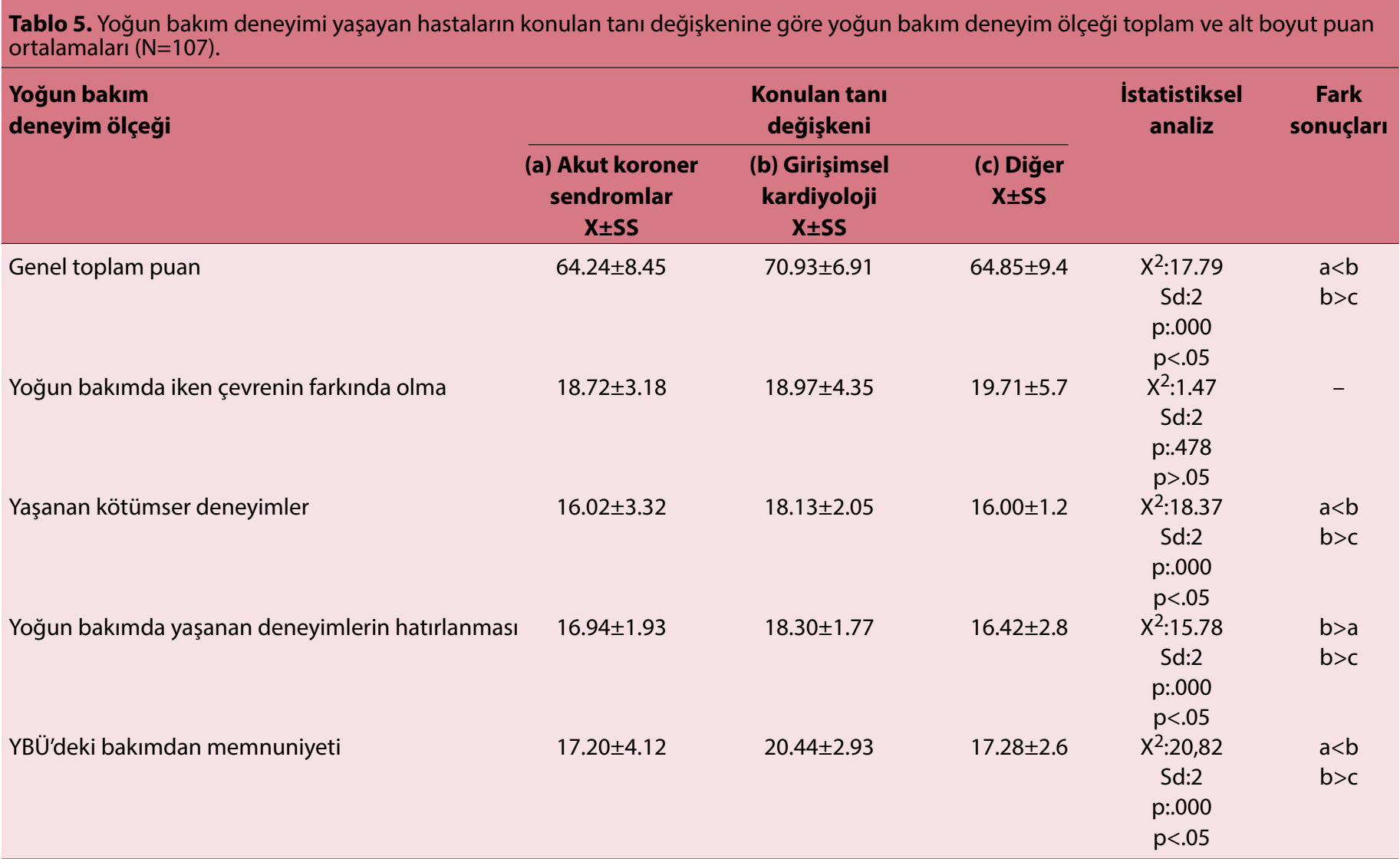

lamalarından anlamlı olarak daha yüksek ve olumlu bulundu $(p<0.05)$. Evli yoğun bakım hastalarının yoğun bakım da yaşanan deneyimlerin hatırlanması alt boyut puan ortalaması bekar hastalara göre daha yüksek bulundu $(p<0.05)$ (Tablo 4). Girişimsel kardiyoloji işlemi amacı ile yoğun bakımda tedavi gören hastaların yoğun bakım deneyimleri toplam puan ortalamaları, yaşanan kötümser deneyimler, yoğun bakımdan memnuniyet ve yoğun bakımda yaşanan deneyimlerin hatırlanması alt boyut puan ortalamaları diğer hastalık tanısı alan gruplara göre daha yüksek ve olumlu bulundu $(p<0.05)$ (Tablo 5).

Yoğun bakımda 1-5 gün arasında yatan yoğun bakım hastalarının yoğun bakımda iken çevrenin farkında olma alt boyut puan ortalaması yoğun bakımda 6 gün ve üzerinde yatan hastalarından daha yüksek ve olumlu bulundu $(p<0.05)$ (Tablo 6).

\section{Tartışma}

Kesitsel türde yapılan, yoğun bakım ünitesinde tedavi gören hastaların yoğun bakım deneyimlerini ve etkileyen faktörleri belirlemek amacıyla toplam 107 katılımcı ile gerçekleştirilen bu araştırmada Yoğun Bakım Deneyim Ölçeği toplam puan ortalamaları $67.0 \pm 8.56$ olarak bulundu. Hin-
Tablo 6. Hastaların yoğun bakımdaki kalıs sürelerine göre yoğun bakım deneyim ölçeği toplam ve alt boyut puan ortalamalarının karşılaştırılması ( $\mathrm{N}=107)$.

\begin{tabular}{|c|c|c|c|}
\hline \multirow[t]{2}{*}{$\begin{array}{l}\text { Yoğun bakım } \\
\text { deneyim ölçeği }\end{array}$} & \multicolumn{2}{|c|}{$\begin{array}{l}\text { Yoğun bakım süresi } \\
\text { değişkeni (Gün) }\end{array}$} & \multirow[t]{2}{*}{$\begin{array}{l}\text { İstatistiksel } \\
\text { analiz }\end{array}$} \\
\hline & $\begin{array}{c}1-5 \\
X \pm S S\end{array}$ & $\begin{array}{c}6 \geq \\
X \pm S S\end{array}$ & \\
\hline Genel toplam puan & $67.45 \pm 8.49$ & $63.76 \pm 8.74$ & $\begin{array}{l}\text { U: } 454.0 \\
\mathrm{p}: .133 \\
\mathrm{p}>.05\end{array}$ \\
\hline $\begin{array}{l}\text { Yoğun bakımda } \\
\text { iken çevrenin } \\
\text { farkında olma }\end{array}$ & $19.45 \pm 3.85$ & $15.30 \pm 3.63$ & $\begin{array}{l}\mathrm{U}: 260.0 \\
\mathrm{p}: .001 \\
\mathrm{p}<.05\end{array}$ \\
\hline $\begin{array}{l}\text { Yaşanan kötümser } \\
\text { deneyimler }\end{array}$ & $16.77 \pm 2.95$ & $17.53 \pm 1.76$ & $\begin{array}{l}\mathrm{U}: 556.5 \\
\mathrm{p}: .600 \\
\mathrm{p}>.05\end{array}$ \\
\hline $\begin{array}{l}\text { Yoğun bakımda } \\
\text { yaşanan deneyimlerin } \\
\text { hatırlanması }\end{array}$ & $17.39 \pm 1.84$ & $17.61 \pm 3.66$ & $\begin{array}{l}\mathrm{U}: 446.5 \\
\mathrm{p}: .111 \\
\mathrm{p}>.05\end{array}$ \\
\hline $\begin{array}{l}\text { YBÜ'deki bakımdan } \\
\text { memnuniyeti }\end{array}$ & $18.68 \pm 3.80$ & $17.30 \pm 3.94$ & $\begin{array}{l}\mathrm{U}: 458.0 \\
\mathrm{p}: .143 \\
\mathrm{p}>.05\end{array}$ \\
\hline
\end{tabular}

tistan ve arkadaşlarının çalışmalarında hastaların yoğun bakım deneyim ölçeği toplam puan ortalaması $59.42 \pm 6.85$, Zaybak ve arkadaşlarının çalışmalarında $57.7 \pm 5.5$ olarak 
bildirilmiştir. ${ }^{[13,3]}$ Çalışma grubumuzdaki hastaların yoğun bakım deneyimlerinin orta düzeyde olduğu söylenebilir.

Çalışmamızda erkek hastaların yoğun bakım deneyimlerinin kadınlara göre daha olumlu olduğu, 61 yaş ve üstünde olan hastaların yoğun bakım deneyimlerinin 60 yaş ve altında olan hastalara göre daha olumlu olduğu, 49 yaş ve altındaki hastaların yaşanan kötümser deneyimleri 50 yaş ve üstü gruba göre daha yüksek ve olumlu olduğu,bekar hastaların yoğun bakım deneyimlerinin evli hastalara göre daha olumlu olduğu belirlendi $(p<0.05)$. Zaybak ve Güneş'in çalışmasında yoğun bakım hastalarında cinsiyet ve eğitimin yoğun bakım deneyimlerini etkilemediği belirlenirken, hastaların medeni durumlarının yoğun bakım deneyimlerini etkilediği, evli hastaların yoğun bakım deneyimlerinin bekar hastalara göre daha olumsuz olduğu belirlenmiştir. ${ }^{[3]}$ Rattray ve arkadaşları yoğun bakım deneyimleri ölçeğinin orijinalini geliştirdikleri çalışmada yoğun bakımı deneyimleyen hastalarda yaş, cinsiyetin yoğun bakım deneyimini olumsuz yönde etkilediğini rapor etmişlerdir. ${ }^{[15]}$ Hintistan ve arkadaşlarının çalışmasında yaş, cinsiyet, eğitim durumu, medeni durum, mesleğin hastaların yoğun bakım deneyimlerini etkilemediği belirlenmiştir. ${ }^{[13]}$ Adsay ve Dedeli'nin çalışmasında ${ }^{[16]}$ kadınların ve yoğun bakımda kalma süresinin 20 gün ve üzerinde olan hastaların yoğun bakım deneyimlerini etkilediği bulunmuştur. ${ }^{[16]}$ Terzi'nin çalışmasında hastalarda cinsiyet, yaş medeni durum, eğitim durumu, meslek ve gelir durumunun yoğun bakım deneyimlerini etkilemediği belirlenmiştir. ${ }^{[1]}$ Yaşla birlikte çoklu kronik hastalık varlığı olmakla birlikte hastaların olumlu baş etme mekanizmaları geliştirmelerinin yaşlı hastaların yoğun bakım deneyimlerini olumlu yönde etkilediği düşünülmektedir. Literatürde yoğun bakımda tedavi gören genç hastaların anksiyete ve stres düzeyleri yükseldikçe olumsuz ve kötü deneyimler yaşadıkları rapor edilmektedir. ${ }^{[3,17,18]}$ Çalışmamızda genel olarak kadınların ve evlilerin yoğun bakım deneyimlerinin, erkeklere ve bekarlara göre daha olumsuz olmasının nedenleri; Türk toplumunun kültürel yapısına bağlı olarak kadın olmak ve evliliğin bireylere getirdiği bir takım rol ve sorumlulukları hastalık nedeniyle yerine getirememe yada çocuklarından ve eşinden ayrı kalmaya bağlı yaşanan stres ve anksiyeteye bağlı olduğu düşünülmektedir. Bu grupta yer alan hastaların hemşirelik bakım girişimlerinde, bu gereksinimleri göz önünde bulundurularak stres ve anksiyete düzeylerini en aza indirecek girişimler planlanmalıdır.

Çalışmamızda yoğun bakımda 1-5 gün arasında yatan ve girişimsel kardiyoloji işlemi uygulanan yoğun bakım hastalarının yoğun bakım deneyimlerinin diğer gruplara göre daha olumlu olduğu belirlendi $(p<0.05)$. Adsay ve Dedeli'nin çalışmasında, ${ }^{[16]}$ yoğun bakım ünitesinde 20 günden daha uzun süre kalan hastaların ölçeğin yoğun bakımda iken çevrenin farkında olma, yaşanan kötümser deneyimler ve yoğun bakım ünitesindeki bakımdan memnuniyet alt boyutlarından aldıkları puan ortalamalarının daha yüksek olduğu bildirilmiştir. ${ }^{[16]}$ Hastalar yaşamı tehdit eden durumlarda (akut miyokard enfarktüsü vb.) yoğun bakım ünitesine plansız olarak kabul edilmektedir. Yoğun bakım ünitesindeki hastalara pek çok yaşam destek sistemlerini içeren (mekanik ventilatör, yoğun i.v. infüzyon tedavileri vb.) bakım ve tedavi yöntemleri uygulanmaktadır. ${ }^{[2]}$ Hastaların bakım gereksinimleri karşılanırken yoğun bakıma plansız yatış yapmış olan hastalara bu konuda hastaların anksiyete düzeylerini azaltacak bireysel hemşirelik girişimleri önerilmektedir. Bu uygulamalar sırasında hastaların ölüm korkusu ile birlikte pek çok olumsuz deneyimleri yaşayabildiği düşünülmektedir.

\section{Çalışmanın Sınırlılıkları}

$\mathrm{Bu}$ araştırma Edirne ilinde yer alan bir Üniversite Hastanesinin YBÜ'nde tedavi gören hastalar ile sınırlı olduğu için bulunan sonuçlar genellenemez.

\section{Sonuç}

$\mathrm{Bu}$ araştırmanın sonucunda; kadın hastaların, 61 yaş ve üstünde olanların, evli olanların, yoğun bakımda 6 gün ve üzerinde tedavi görenlerin, akut miyokart infarktüsü geçirenlerin yoğun bakım deneyimlerinin daha olumsuz olduğu bulundu. Bu sonuçlar doğrultusunda; yoğun bakım ünitesine kabul edilen bireylerin yaş, cinsiyet, eğitim, medeni durum gibi bireysel özellikleri dikkatte alınarak hastaya özgü hemşirelik bakımının planlanması, uygulanması ve bakım sonuçlarının değerlendirilmesi, yoğun bakım ünitesine yatışı yapılan hastalara, ünitede yapılan tedavi ve bakım uygulamaları hakkında bilgi verilmesi, ilgili protokollerin hasta ve ailesine açıklanması ve bu konuda kurum protokolleri hazırlanarak eğitim kitapçıklarının hazırlanması, hastaların yoğun bakıma uyumunu kolaylaştırıcı girişimlerin planlanması ve uygulanması, yoğun bakım ünitesinde hastalarla yoğun bakım hemşireleri tarafından sürekli ve etkili iletişim kurulması, yoğun bakım ünitesinde tedavi gören hastaların farkındalık düzeylerinin arttırılmasına yönelik girişimlerin planlanması, yoğun bakım hastalarının deneyimlerinin geçerli ve güvenilir ölçeklerle hemşireler tarafından belirli aralıkla değerlendirilmesi, gelecek araştırmalarda daha fazla sayıda hasta grupları ile karşılaştırmalı, kanıta dayalı hemşirelik uygulamaları içeren çalışmalar yapılması önerilebilir.

\section{Teşekkür}

Çalışmamızda emeği geçen/katkı sağlayan Üniversite Sağlık Uygulama Merkezi çalışanlarına ve hastalarına teşekkür ederiz. 
Hakem Değerlendirmesi: Dış bağımsız.

Çıkar Çatışması: Yazarlar arasında herhangi bir çıkar çatışması bulunmamaktadır.

Yazarlık Katkıları: Konsept: S.Ü.; Dizayn: S.Ü., I.D.S.; Veri Toplama veya İşleme: I.D.S.; Analiz veya Yorumlama: S.Ü., I.D.S.; Literatür Arama: I.D.S., S.Ü.; Yazan: S.Ü., I.D.S.

\section{Kaynaklar}

1. Terzi B, Kaya N. Yoğun bakım hastasında hemşirelik bakımı. Yoğun Bakım Dergisi 2011;1:21-524. [CrossRef]

2. Özdemir L. Koroner yoğun bakımda kalan hastaların deneyimlerinin belirlenmesi. Hemşirelikte Araştırma Geliştirme Dergisi 2010;1:5-12.

3. Zaybak A, Güneş ÜY. Hastaların yoğun bakım deneyimlerinin incelenmesi.Ege Üniversitesi Hemşirelik Yüksek Okulu Dergisi 2010;26:17-26.

4. Williams CMA. The identification of familymembers' contributiontopatients' care in theintensivecareunit: a naturalisticinquiry. British Association of Critical CareNurses, Nursing in Critical Care 2005;10:6-14. [CrossRef]

5. Efil S, Kurucu MN, Eser O. Beyin cerrahi yoğun bakımında takip edilen hastaların hasta yakını ziyaret sıklığının ve hemşire ile olan iletişimin hastanın iyileşmesine etkisi.Kocatepe Tıp Dergisi 2011;12:151-5.

6. Tunçay GY, Uçar H. Hastaların yoğun bakım ünitesinin fiziksel ortam özelliklerine ilişkin görüşleri. Hacettepe Üniversitesi Sağlık Bilimleri Fakültesi Hemşirelik Dergisi 2010;33-46.

7. Alaca Ç, Yiğit R, Özcan A. Yoğun bakım ünitesinde yatan hastaların hastalık sürecinde yaşadığı deneyimler konusunda hasta ve hemşire görüşlerinin karşılaştırılması.Psikiyatri Hemşireliği Dergisi 2011;2:69-74.

8. T.C. Sağlık Bakanlığı Temel Sağlık Hizmetleri Genel Müdürlüğü. Kalp Ve Damar Hastalıklarını Önleme Ve Kontrol Programı Eylem Planı (2015-2020). Ankara; Anıl Reklam Matbaa, 2015.

9. Altıntaş ND, İzdeş S, Şen P, Öcal H, But A. Karma yoğun bakımda yatan cerrahi ve dahili hastaların retrospektif olarak değerlendirilmesi.Yoğun Bakım Dergisi 2012;1:5-8.

10. Aygencel G, Türkoğlu M. Yoğun bakımda uzun yatan hastaların özellikleri, sonuçları ve maliyetleri.Yoğun Bakım Dergisi
2011;3:53-8. [CrossRef]

11. Türker İ, Gürsoy H, Özyılkan E, Dönderici Ö, Kaya P, Deveci B. Dahiliye yoğun bakım ünitesine yatan hastaların yatış nedenlerinin ve sürelerinin incelenmesi. İç Hastalıkları Dergisi 2008; 15:102-4.

12. Akkuş N, Biberoğlu K, Tarhan O. Yoğun bakım ünitesinde infeksiyon risk faktörleri: Dokuz Eylül Üniversitesi Tıp Fakültesi deneyimi. Hastane İnfeksiyonları Dergisi 1997;1:101-5.

13. Hintistan S, Nural N, Öztürk H. Yoğun bakım ünitesinde yatan hastaların deneyimleri. Yoğun Bakım Hemşireliği Dergisi 2009;13:40-4.

14. Durna Z, Can G, Özcan Ş. Akut miyokardinfarktüsü geçiren hastalarda koroner yoğun bakım ortamı stresörlerinin ve stres düzeylerini etkileyen faktörlerin saptanması. Yoğun Bakım Hemşireleri Dergisi 1997;1:25-31.

15. RattrayJ, Johnston M,Wildsmith J. The intensive care experience: development of the ICE questionnaire. Journal of Advanced Nursing 2004;47:64-73. [CrossRef]

16. Adsay E, Dedeli Ö. Yoğun bakım ünitesinden taburcu olan hastaların yoğun bakım deneyimlerinin değerlendirilmesi. Yoğun Bakım Dergisi 2015;6:90-7. [CrossRef]

17. Karadakovan A,Aslan EF. Dahili ve Cerrahi Hastalıklarda Bakım. Nobel Kitabevi;2011;5-9.

18. Bodyak B. Akut miyokard infarktüsüve anstabil angina peltoris.Sted 2001;10:378-81.

19. Demir Y, Korhan E, Eşer İ, Khorshıd L. Yoğun Bakım Deneyim Ölçeği'nin geçerlilik ve güvenirlilik çalışması. Türkiye Klinikleri J NursSci 2009;1:1-11.

20. Çelikel T. Dünyada ve Türkiye'de yoğun bakım uzmanlığı.Yoğun Bakım Dergisi 2001;1:5-9.

21. Şahinoğlu AH. Yoğun Bakım Sorunları ve Tedavileri. Türkiye Klinikleri Yayın Evi. Ankara: 1992.

22. Berthelson PG, Cronquist $M$. The first intensive care unit in the world.Copenhagen 1953.Acta Anasesthesiol Scand 2003;47:1190-5. [CrossRef]

23. Sezgin AT, Yıldırır A, Müderrisoğlu H. Akur koroner sendromlar.Yoğun Bakım Dergisi 2005;5:5-25.

24. Enver R, Özkan AA. Akut Miyokard İnfarktüsü Trombolitik Tedavisi. Tatlıdil Matbaa. İstanbul 1998. 